\title{
Power to the People: by Dana Ott \\ The Role of Electronic Media \\ in Promoting Democracy in Africa
}

This paper presents an analysis of the role of electronic media in promoting the formation of democratic political regimes in Africa. With the dramatic expansion of various forms of electronic interchange, including electronic mail and the Internet, opportunities for communication across national boundaries, and cross-fertilization of ideas are greater than ever before. This article argues that access to electronic information can have a positive impact in promoting democracy in Africa, by providing civil society with greater leverage vis-à-vis the state and political elites. However, without parallel efforts to insure that access to the Internet is not restricted to urban, elite populations, political instability may result. The paper is structured as follows: Section I makes the theoretical case for the role of increased information access and communication in the promotion of democratic political regimes. Section II presents an overview of the state of electronic access in Africa, including indigenous and international donor supported initiatives to promote African connectivity. Section III presents an empirical analysis of the relationship between access to electronic media and political participation and democratization in Africa. Section IV considers methods to increase usage of electronic media as a tool for increased participation and democratization in Africa.

\section{Contents}

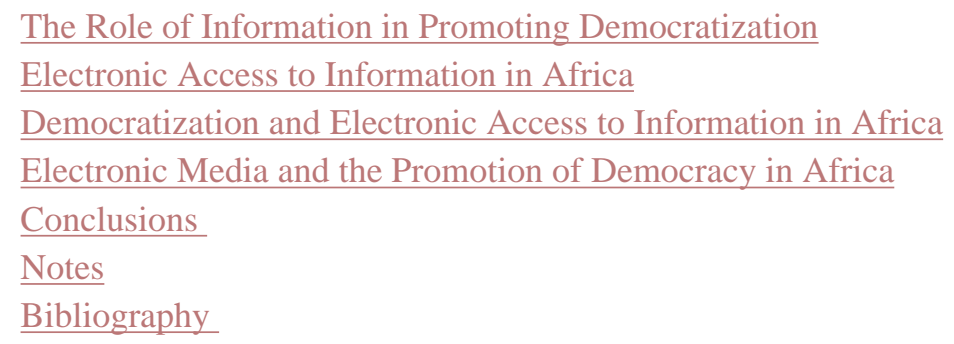

"The general belief holds that representative government is the only form of democracy that is feasible in today's sprawling, heterogeneous nation-states. However, interactive telecommunications now make it possible for tens of millions 
of widely dispersed citizens to receive the information they need to carry out the business of government themselves, gain admission to the political realm, and retrieve at least some of the power over their own lives and goods that many believe their elected leaders are squandering" [1]].

Since the earliest conceptualization and discussion of the political, communication has held an equally prominent position, both in terms of its necessity for political ideas to be transmitted and replicated, and as a tool by which political actors seek to ensure the predominance of their ideas through improved methods of communication [2]. In the polis, as conceived

by Aristotle, direct communication among and between all the political actors in the system was an attainable ideal. The growth of larger and more geographically diverse states necessitated the development of alternative modes of interaction as societies moved from direct political interaction to representative political action. Those chosen to represent the interests of others in the political system have historically used a variety of methods to obtain information about their constituents' preferences, including physically touring their districts periodically, reading letters from constituents, and polling their constituents about key issues. All these methods can be time consuming and costly to employ, limiting the frequency with which they can be used and by extension the quality of information which can be regularly obtained. However, the changing nature of communication ushered in by the dawning of the age of electronic communications, and the concomitant decline in the costs of communication on a global scale has profound implications for political interaction among representatives and their constituents, and for economic and political development throughout the world. This paper focuses explicitly on the impact these changes may have on political communication and potentially on the formation and maintenance of democratic political regimes in Africa.

\section{The Role of Information in Promoting Democratization}

"Now as in the past it is difficult to separate the quality and cast of political life from the methods of communication that sustain it. But behind the changes wrought by technology, organization, and the scale of politics, there is also a certain sameness. Linked to the communication structures which characterize a society, and in fact inseparable from them, are numerous face-to-face relationships. Much of the political business of the world is still done in such situations, and it would indeed provide a mistaken view of the communication process to concentrate on machines and organizations to the exclusion of the face-to-face groupings which are a prominent feature of all political systems" [3]].

Writing over thirty years ago, Richard Fagen cautioned against reading too much into the impact of technological developments such as radio and television on political communication and ultimately on the conduct of politics. He argued that while technology does matter in the functioning of a political system, that there are more elemental relationships of power in political communication that are unaffected or barely affected by the development of enhanced methods of communication such as television and radio because those relationships are the one-to-one interactions that remain a critical part of the political process. In other words, the political elite will always be small enough to remain relatively unaffected by changes in communications. This paper argues that while it is certainly true that the actual decision-making in a political system (even a democratic one) may remain concentrated at the level of a few individuals, the complexity of information which those individuals use to engage in decision-making processes (especially constituency feedback) is equally important and is subject to influence by the changing nature of communications. As electronic communication enables citizens to directly and instantaneously convey their wishes to their representatives with ever decreasing costs, the nature of political interaction is likely to change. There are several direct consequences which can be highlighted: 
In what Grossman (1996) calls the "Electronic Republic", the power of individual citizens is increased is several ways: through greater access, and greater influence. There is greater access to those who represent the individual in the political system, and to information about issues, decisions and pending legislation that might affect the individual. There is greater influence both as an individual who can more easily communicate his or her views on a topic directly to elected representatives, and indirectly through easier access to issue advocacy organizations. There are other, more subtle implications of this shift in public power for elected representatives and for citizens themselves. For representatives, this could mean the transformation in the definition of their role; from the more traditional conception of the representative as someone who is selected to represent his or her constituents by considering the facts surrounding various issues and making carefully reasoned decisions on that basis with the interests of his or her constituents in mind; and someone who is merely a proxy for his or her constituents, adding up the constituency responses on a given issue and voting accordingly. The electronic media has given a larger percentage of constituents than ever before the ability to easily and qui ckly transmit their opinions on public policy issues to their representatives. The danger is that whereas a representative is supposed to consider what is best for his or her district as a whole (including all members of the district), a proxy is constrained to represent the majority viewpoint. This dominance of a majority faction could have serious repercussions in the African context.

At the same time, and in the same vein, the opportunity costs of participation are reduced. Electronic access could potentially erase disparities of distance and geography, minimizing the rural-urban distinction that has had significant political implications in Africa in the past. Aside from these direct consequences, Grossman sees as an additional consequence a power shift in the electronic republic:

"The big losers in the present-day reshuffling and resurgence of public influence are traditional institutions that have served as the main intermediaries between the government and its citizens - the political parties, labor unions, civic associations, even the commentators and correspondents in the mainstream press" [4].

By empowering ordinary citizens to participate more directly in their political system, Grossman argues, electronic communications increases the role of citizens in the policymaking process at the expense of the political "middlemen" who have historically provided the forum by which ordinary citizens could make their interests on specific issues known through interest aggregation and representation. Not only this, but electronic communication and participation in politics may eventually lead to a more direct democracy in which general participation is increased with both potentially positive and negative consequences. In larger democracies such as the United States, there is a potentially troubling outcome:

"As the political system grows ever more responsive to majority impulses, and the legislative and executive branches feel increased pressure to bend to the public will, the judiciary remains the branch of government in the best position to serve as a brake upon the people ... In the electronic republic, the judiciary will have the increasingly difficult and sensitive role of protecting the rights of unpopular minorities and thwarting the popular will when it gets out of hand... Protecting the essentially anti-majoritarian doctrine of judicial review will become the key to preserving democracy in the electronic republic and preventing it from succumbing eventually to a popular tyranny or a demagogic leader" [5].

In other words, James Madison's concern in the early days of the United States democracy over controlling the effects of "majority faction" may once again become a problem in an electronic republic [6]. That this issue could become a concern even in the United States, where strong legal barriers exist to this "tyranny of the majority," has significant implications for the political impact of electronic communications in African countries where factionalism is already a problem and there are weak safeguards to majority domination. 
In terms of the role of electronic media in promoting democratic outcomes, it has been well established that radio and television can have significant impact on political participation in developed countries [7]. The case is less clear for the impact of the Internet on popular participation. A recent study on the impact of the Internet on the 1996 Presidential elections in the United States argues that:

"The most "wired" of political participators did make some use of the Net to communicate with their elected officials, but for the most part traditional means of communication were still much more important... Where mobilization is concerned, political organizations appear to have made little widespread use of the Internet as a tool of communication and persuasion - yet. Although the Internet may already be significant as a passive information resource about public life, I find that it is still far from transforming active political communication on a wide scale" [8].

Bimber deliberately targeted his survey at those individuals most likely to be involved in political activity, and still found that Internet was not as prominent in their political activity as the literature would predict. It could be argued, however, that in the United States, where many avenues to political participation already exist, and where the opportunity cost of participation is quite low, that the Internet does not provide a sufficient "added value" to make it a better alternative than more traditional methods of political communication. Still, Bimber shows that we would be well advised not to overstate the potential impact of the Internet on fostering better or more political participation.

It has also been argued that the impact of electronic media on democratization can be distinguished by is its potential range versus print media, particularly in the developing world. Radio and television have long provided a source of information for the millions of people who are illiterate and/or unable to afford the cost of newspapers. But the Internet provides an interactive component that radio and television lack. As Graeme Browning and Daniel Weitzner note:

"The Internet's greatest strength, however, is its ability to support simultaneous, interactive communications among many people. Unlike the telephone, which primarily supports one-to-one communications, or radio and television, where information flows in only one direction, from a single source to an audience that can only listen passively, the Net allows information to flow back and forth among millions of sources at practically the same time".

The implication is that millions of people can be exposed to a medium in which they have an active role to play and can influence political as well as other outcomes. However, like newspapers, active use of the Internet requires literacy. Perhaps more troubling, access to the Internet will likely require literacy in English, for the most part, to enjoy the benefits. For French- and Portuguese-speaking African countries, this is yet another hurdle on top of the financial and infrastructure constraints that many African countries already face to widespread Internet connectivity. Newspapers in Africa have traditionally been utilized primarily by the elite and urban population. It is possible that Internet access in many African countries will merely cement and potentially expand these disparities, despite the best efforts of donors and others. This is explored in greater depth in Sections III and IV. The next section gives a brief overview of the current state of electronic communications in Africa.

\section{Electronic Access to Information in Africa}

Electronic communications is not a new phenomenon in Africa. Radio and television have played a significant role in political life in most African countries since independence. Radio and television ownership and use continue to expand even 
as the Internet begins to make inroads into Africa. This analysis, while focused primarily on the Internet, also considers the status of radio and television in Africa, as well as their impact on the democratization process.

Radio/Television. Despite the growing popularity of the Internet, radio and television still represent the mode through which the majority of Africans receive information about national and international events. Radio is by far the most prominent source of information for Africans in general, even when compared to television or newspapers. For example, a 1995 media survey in Niger's two largest cities, conducted by a French firm with assistance from U. S. Information Agency (USIA), found that radio sets were widely available, while television and satellite television were not. Radio news (both from foreign stations such as Voice of America (VOA), and local stations) was a major source of information for people, even in these urban locations. UNESCO reports echo these findings - their Statistical Survey shows that average radio usage throughout sub-Saharan Africa (145 transmitters per 1,000 people) is far greater than television (23 per 1,000 people) or newspapers (circulation of 10 per 1,000). Radio and television broadcasts can be received (provided you have a receiver) throughout most of Africa, and literacy is not a requirement as it is for newspaper consumption. Figure 1 shows the trend of radio, television and newspaper usage in sub-Saharan Africa for the past 20 years.

\section{Media Usage in Africa: 1970-1995}

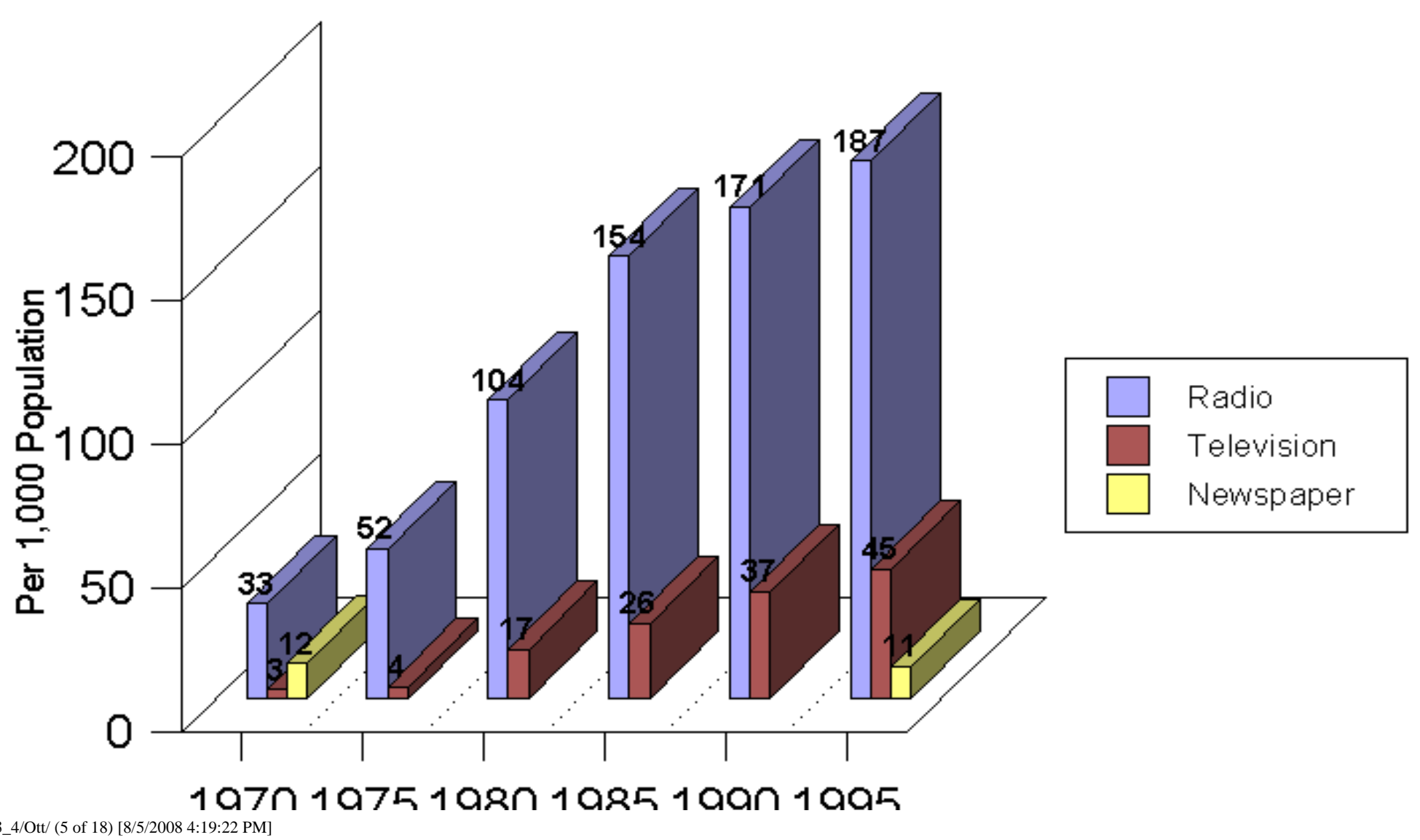


Figure 1 illustrates the ongoing relevance of electronic media (particularly radio) in Africa, particularly when compared with similar figures for print media (newspapers) which show no increase in newspaper consumption in a 22-year period. Even television, which has faced greater obstacles in Africa than radio because of startup costs for television stations, and costs to viewers to obtain televisions, shows a moderate increase during this period. From these data, it seems logical to assume that electronic media will continue to occupy a dominant position in Africa, particularly as a source of political information. We would expect, therefore, to find that increased access to electronic media would be correlated with the transitions to democracy which have been occurring recently in Africa. This assumption is tested empirically in Section III.

\section{Today 44 of the 54 nations in Africa have some form of Internet access in their capital cities.}

Internet. It is an astounding fact that where the Internet barely existed in Africa even five years ago, today 44 of the 54 nations in Africa have some form of Internet access in their capital cities. But as Mike Jensen notes, "Of the countries with full Internet access, only Burkina Faso, Mauritius, Morocco, Senegal, South Africa and Zimbabwe have pervasive local dialup facilities outside of the capital city, while Benin, Botswana, Egypt, and Kenya have services in the second major city" [9]. Jensen notes that access costs are generally higher in Africa than elsewhere, and Aden (1995) argues that this may be related to the profit margins of the telecommunications sector in African countries, where the revenue per subscriber line is twice as high as in Europe [10]. Aden argues that the two greatest impediments to the development of electronic communication in Africa are insufficient infrastructure and regulatory barriers. Infrastructure limitations include such problems as scarce and/or poor quality telephone lines, unreliable power supplies, outdated equipment, and a lack of knowledge and training. Regulatory barriers include government monopolies on telecommunications, high access rates for telephone service, and legal disincentives to foreign investment. The result is that for much of Africa:

"In the majority of cases national telecom operators are also guided by policy makers with less background in telecommunications technology and its value for development. These politicians often perceive telecommunications as trivial public utility; sometimes as a utility for "high officials." The guidance of policy makers has made telecom operations management inefficient and unconfident in decision making. Such arrangement has blocked visions towards deregulation and increased conflict in adopting the most appropriate deregulation and privatization models based on national situations" [11]. 
partnership with African governments and NGOs including USAID's Leland Initiative, UNDP, and PADIS, among others. There are several Web sites which provide links and comprehensive overviews of ongoing projects, including Bellanet and Information Systems in Developing Countries. The next section explores the relationship between electronic media and democratization in Africa in greater detail.

\section{Democratization and Electronic Access to Information in Africa}

Is access to the Internet and other forms of electronic media related to the formation of representative political systems in Africa and elsewhere? Kedzie (1995) makes a strong case for a global linkage between democracy (as operationalized by Freedom House) and interconnectivity, which he defines as access to e-mail. Using sophisticated statistical analysis, he finds a strong, positive and causal relationship between interconnectivity and democracy; a relationship that is stronger in his model than more traditional causal variables for democracy such as per capita GNP and education. These findings are very significant, and the implications for the larger global efforts to promote interconnectivity probably are quite dramatic.

However, a few caveats to this analysis are also in order. Specifically, for this analysis Kedzie chooses a measure of interconnectivity that is likely to have the strongest impact on democracy, as he himself notes, "e-mail, but not necessarily the other services [such as Internet], offers the specific capability that is hypothesized to have dynamic implications for democratization: multidirectional discourse across borders in a timely and inexpensive manner, unbounded by geographic and institutional constraints" [12]. While e-mail capability is certainly the most sought after and most common form of connectivity in the African context, other aspects of the larger "Internet" also have great potential to enhance democracy in Africa - particularly access to information from a variety of sources other than the state. While e-mail is certainly a major component of the electronic media, it does not capture other components of Internet access which may also be worth examining, such as the number of Internet Service Providers (ISPs) in a country or the cost for monthly access. A closer examination of Kedzie's data for Africa specifically reveals a more ambiguous picture than the overall analysis presents. A scatterplot of the regression line for the Africa region presented in Kedzie (1996) shows a strong cluster of data points at the lower end of the scale - meaning that countries with less interconnectivity tend to be less democratic (as defined by Freedom House scores).

There are also a significant number of countries which are more democratic but have low interconnectivity. The number of countries which could be classified as having medium or high interconnectivity is very small, which does not allow for verification in the African context of the positive nature of the relationship between interconnectivity and democracy that Kedzie claims. In other words, neither democratic or non-democratic countries in Africa appear to have much interconnectivity. As a result it is unclear from this data whether increases in interconnectivity will necessarily result in greater democracy in Africa. In addition, there is no attempt to examine other forms of electronic media which might be far more relevant in the African context such as radio or television. Considering the persistently high illiteracy rates in Africa, it is unlikely that a significant percentage of Africans will be able to use the Internet directly in the near future. What is perhaps more important for Africans is the presence of alternative sources of information (such as independent and national radio) which have the capacity to disseminate knowledge from the Internet to a broader audience. Therefore, as a component of this analysis, a quantitative analysis was undertaken to examine these relationships more systematically and determine if any correlations could be found.

The dataset used in this analysis was compiled using data from several sources, including Africa South of the Sahara, The World Media Handbook, and UNESCO Statistics on Education. A database codebook listing data sources and years 
for which the data was collected is attached in Appendix A.

The findings of the analysis are displayed in Table 1. Preliminary results show that, at least in Africa, measures of electronic media access are not significantly correlated with democratization at present. The measure of prevalence of radio (RADIOREC) was significantly associated (at the lowest level of significance) with the overall measure of democracy (FREEDOM) in two of the five years for which data was available, and with the measure of political rights (POLRIGHT) only once over the five years of data. The measure of civil liberties (CIVIL) was not significantly associated with any of the measures of freedom over the five years of data. The measure of independent radio stations (INDRAD) was not significantly associated with any of the measures of democracy in either of the two years for which data was available. The other measures of electronic media access; the number of Internet Service Providers (ISPs) and monthly fees for Internet access, were also not significantly associated with measures of democracy. However, only one year of data was available for these measures, so these results cannot be considered conclusive. The number of ISPs was significantly correlated with the degree of economic freedom, which is an outcome we would expect, given the relationship between government control of markets and proliferation of private firms in any industry. There was also a significant relationship between the number of ISPs and the monthly fees for access to the Internet - confirming the need for competition in this area to reduce access costs for users. The most interesting findings was for the measure of print media access (daily newspaper circulation) which shows the strongest overall correlations with democracy; a relationship that holds true over the 25 year period of available data for this variable. This statistical data, although preliminary, in combination with the findings of others such as Bimber (1997) who have tried to determine the nature of the effect of electronic media on political participation, suggest that some caution when espousing the political benefits of electronic media is warranted. This is not to say that electronic media, and the Internet in particular, do not have a substantive role to play in achieving development and education related goals. However, at this time it is not possible to show a meaningful link between the various forms of electronic media in Africa and political outcomes such as democracy. This does not mean that such linkages do not exist. After all, the Internet in particular is relatively new to Africa, and measurable political effects may not be detectable for some time. In the light of these findings, Section IV offers conclusions and recommendations about the role of electronic media in political life in Africa.

Table 1: Correlations between Democracy and Media in Africa

\section{Daily Newspaper Circulation per 1,000 Inhabitants (NEWSPCIR)}

\begin{tabular}{|c|c|c|c|c|c|}
\hline & $\mathbf{1 9 7 5}$ & $\mathbf{1 9 8 0}$ & $\mathbf{1 9 8 5}$ & $\mathbf{1 9 9 0}$ & $\mathbf{1 9 9 4}$ \\
\hline & & & & & \\
\hline FREEDOM & $-.4745^{* *}$ & $-.6339^{* * *}$ & $-.4797 * *$ & $-.3638^{*}$ & $-.3122^{*}$ \\
\hline POLRIGHT & $-.5480^{* * *}$ & $-.6020^{* * *}$ & $-.4273 * *$ & $-.3673 *$ & -.2725 \\
\hline CIVIL & $-.5064^{* * *}$ & $-.5092 * *$ & $-.4388^{* *}$ & -.2333 & $-.3527^{*}$ \\
\hline
\end{tabular}


Number of Radio Receivers per 1,000 inhabitants (RADIOREC)

\begin{tabular}{|c|c|c|c|c|c|}
\hline & $\mathbf{1 9 7 5}$ & $\mathbf{1 9 8 0}$ & $\mathbf{1 9 8 5}$ & $\mathbf{1 9 9 0}$ & $\mathbf{1 9 9 4}$ \\
\hline & & & & & \\
\hline & & & & & \\
\hline FREEDOM & $-.3447^{*}$ & -.2159 & -.1782 & $-.3001^{*}$ & -.0790 \\
\hline POLRIGHT & $-.3621^{*}$ & -.1678 & -.1942 & -.1064 & -.0293 \\
\hline CIVIL & -.2398 & -.2516 & .0032 & .0117 & -.1762 \\
\hline
\end{tabular}

Number of Independent Radio Stations (INDRAD)

\begin{tabular}{|c|c|c|}
\hline & 1995 & 1997 \\
\hline & & \\
\hline FREEDOM & -.1033 & .0021 \\
\hline POLRIGHT & -.0676 & -.0299 \\
\hline CIVIL & -.0662 & -.1145 \\
\hline
\end{tabular}

Number of Internet Service Providers (ISP)

\begin{tabular}{|c|c|}
\hline & 1997 \\
\hline ECONFREE & $-.3281 *$ \\
\hline FREEDOM & -.2429 \\
\hline POLRIGHT & -.1865 \\
\hline
\end{tabular}




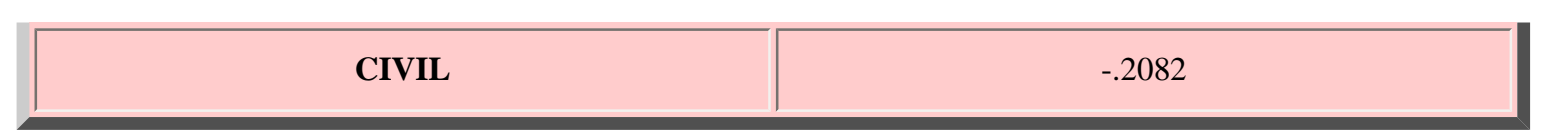

Monthly Fee for Internet Access (MONTHFEE)

\begin{tabular}{|c|c|}
\hline & 1997 \\
\hline ECONFREE & -.1158 \\
\hline FREEDOM & .2952 \\
\hline POLRIGHT & .2083 \\
\hline CIVIL & .1537 \\
\hline ISP & $-.4205^{*}$ \\
\hline
\end{tabular}

\section{*** significant at the .001 level \\ ** significant at the .01 level \\ * significant at the .05 level}

\section{Electronic Media and The Promotion of Democracy in Africa}

"The information revolution could help level the international playing field in terms of opportunities for social and economic development. However, if appropriate care is not taken, the same revolution instead could lead to increasing disparities in incomes and information access, across regions, countries, areas within countries, income groups, communities and individuals... Donors should strongly encourage the development of electronic networking in Africa in directions which will reduce discrepancies between areas and social groups" [1ㅡ] .

There is no doubt that the electronic media (particularly the Internet) can profoundly influence the economic and political development of African states, and affect their role in the global economic and political system as well. To what extent those effects will be positive and sustainable will depend on a myriad of factors, some predictable and others not. This analysis has attempted to address only the narrowest of issues within this broader spectrum; specifically, what potential electronic media have to contribute to political outcomes in Africa such as democratization.

There are a number of conclusions and broader implications that can be drawn out from the material presented here: 
1. At present, there is no empirical evidence that electronic media have thus far contributed to "democracy" in Africa. Despite the long-standing presence of both radio and television in some African countries, there appears to be little linkage between access to these forms of media and political democracy. This may be the result of the state control of radio and television for much of the period for which data is available. It is only in the last five years that private radio and television has been allowed to exist in many African countries, and some lag time may be required for effects to become noticeable. In addition, the impact of electronic media on political activity is difficult to measure quantitatively across the continent. As Ronning (1994) argues:

"Potentially radio is a very democratic medium which when used in a decentralized manner may give local people and communities an opportunity to express their grievances in representative discussions. This however presupposes the establishment of decentralized structures and local and community radio stations as well as radio stations representing the views of organizations in civil society such as trade unions" [14].

\section{There is no empirical evidence that electronic media have thus far contributed to - "democracy" in Africa.}

For much of Africa, efforts to decentralize power and to establish community radio are in a more preliminary state, which limits the ability of this analysis to capture their impact. Further, expansion of television is much more problematic for Africa, requiring a substantially greater outlay of capital resources and is therefore less likely to become a means for distribution of independent sources of information.

2. There is evidence that greater access to print media is associated with higher levels of democracy in Africa, an association that holds up over a 25+ year time span. But it also has limitations above and beyond the literacy constraint, as Ronning notes:

"The most diversified medium in Africa is the press... The major complaint against the daily press in the region which is relevant both for the official and the independent press is that too little attention is being given to journalistic excellence, and that the news and stories are too centered around the interests of a relatively small section of society" [15].

It is also interesting that the strength of the correlation between newspaper circulation and democracy across Africa has been declining over time, ironically at the same time that levels of overall democracy in Africa are increasing. This is likely the result of stagnant literacy rates in much of Africa. 
3. The Internet appears to hold great potential to improve access to information in Africa. In particular, great benefits can be derived through ongoing efforts in distance learning and other similar methods. Education in and of itself is a great need in Africa, but using electronic technologies to further that goal also has the additional benefit of ultimately enabling more Africans to gain access to the Internet by increasing overall literacy. At this time, it is unclear what the potential is of the Internet to influence political outcomes, since preliminary studies in the United States (one of the most wired places on earth) show little impact. It could also be argued, however, that there are already sufficient opportunities to provide political input in the United States and the Internet gets lost in the larger array of choices. In Africa, on the other hand, there are very few opportunities and it is possible that the Internet could become a major tool by which NGOs and citizens exert political influence. At this juncture there simply isn't enough evidence to point in one direction or the other.

4. A critical issue for the spread of Internet technology across Africa will continue to be the question of access. At this time, in many African countries access is limited to a select few - typically urban elites who gain access either through universities or non-governmental organizations. Fagen argues that stripped of all the complexity - the basic question that must arise in any discussion of the impact of these new technologies on communication is, "Who shall control the new instruments of communication, and for what purposes shall they be used?" [16]. In Africa, this question may have to be answered at two levels. On the one hand, initiatives by USAID such as the Leland Initiative, along with efforts of other donors, may allow African nations to become players in the international system by enabling them to access the information they require to do so. On the other hand, such efforts may also widen the gap between haves and have nots, or deepen existing cleavages within individual African countries, creating the potential for political instability if specific efforts are not undertaken to address the problem.

\section{Conclusions}

This paper has argued that the Internet has great potential to impact the formation and maintenance of democratic political systems in Africa, both positively and negatively. Access to alternative sources of information, as well as the capacity to overcome limited availability of print media, have the potential to strongly affect the political status quo in much of Africa. At the same time, if access is limited to traditional advantaged groups in Africa, there may be negative consequences resulting from the cementing of economic and social inequalities. At this time, it is still difficult to establish any empirical linkages between measures of access to electronic media and democratization in Africa. This may be the result of several factors, including the relative newness of the Internet in Africa, and state control of other forms of electronic media until very recently. The reality is that whether Africa is prepared or not, the Internet exists and will continue to expand and change to meet the needs of its global users. The challenge for Africa, and for those who care about it, is see that the Internet is used in a positive and sustainable manner, both within and without.

\section{Appendix A: Codebook for Africa Connectivity Dataset}


Power to the People: The Role of Electronic Media in Promoting Democracy in Africa by Dana Ott

\begin{tabular}{|c|c|c|c|}
\hline Variable Name & Description & Source & Years \\
\hline COUNTRY & All African Countries & N/A & 1980-1997 \\
\hline YEAR & Year & N/A & $1980-1997$ \\
\hline FREEDOM & $\begin{array}{c}\text { Summary figure for overall } \\
\text { Freedom House ranking; } \\
\text { 1=Free, } 2=\text { =Partly Free, } 3=\text { Not } \\
\text { Free }\end{array}$ & Freedom House & $1980-1997$ \\
\hline POLRIGHT & $\begin{array}{l}\text { Political Rights score as } \\
\text { assigned by Freedom House }\end{array}$ & Freedom House & $1980-1997$ \\
\hline CIVIL & $\begin{array}{l}\text { Civil Liberties score as } \\
\text { assigned by Freedom House }\end{array}$ & Freedom House & $1980-1997$ \\
\hline RADIOREC & $\begin{array}{c}\text { Number of Receivers per } 1,000 \\
\text { inhabitants }\end{array}$ & UNESCO & 1980, 1985, 1990, 1994 \\
\hline
\end{tabular}




\begin{tabular}{|c|c|c|c|}
\hline NEWSPCIR & $\begin{array}{l}\text { Daily Newspaper Circulation } \\
\text { per } 1,000 \text { inhabitants }\end{array}$ & UNESCO & 1980, 1985, 1990, 1994 \\
\hline ISP & $\begin{array}{c}\text { Number of Internet/Email } \\
\text { service Providers }\end{array}$ & & 1997 \\
\hline MONTHFEE & $\begin{array}{l}\text { Rate (USD) per Month for } \\
\text { Internet Subscription - Note: } \\
\text { where more than one provider } \\
\text { exists, lowest rate for } \\
\text { individuals was selected }\end{array}$ & & 1997 \\
\hline INDRAD & $\begin{array}{c}\text { Number of independent radio } \\
\text { stations }\end{array}$ & $\begin{array}{l}\text { Africa South of the } \\
\text { Sahara }\end{array}$ & 1995, 1997 \\
\hline ECONFREE & Index of Economic Freedom & Heritage Foundation & 1997 \\
\hline
\end{tabular}

\section{About the Author}

Dana Ott is Program Analyst in the Africa Bureau, Office of Sustainable Development of the U. S. Agency for International Development in Washington, D. C.

e-mail: dott@usaid.gov

\section{Notes}

1. Lawrence K. Grossman, 1996. The Electronic Republic: Reshaping Democracy in the Information Age. N. Y.: Penguin, p. 6. 
2. The views presented herein are those of the author and should not be interpreted as reflecting those of the U. S. Agency for International Development.

3. Richard R. Fagen, 1966. Politics and Communication. Boston: Little, Brown, p. 3.

4. Lawrence K. Grossman, 1996. The Electronic Republic, p. 16.

5. Grossman, 1996. The Electronic Republic, pp. 162-163.

6. James Madison, 1787. Federalist Papers: Federalist No. 10, From the New York Packet, Friday, November 23, at http://lcweb2.loc.gov/const/fed query.html

7. See, among others, Darrell M. West, 1993. Air Wars: Television Advertising in Election Campaigns, 1952-1992. Washington D. C.: Congressional Quarterly; and, Shanto Iyengar, Donald R. Kinder and Benjamin I. Page, 1989. News That Matters: Television and American Opinion. Chicago: University of Chicago Press.

8. Bruce Bimber, 1997. "The Internet and Political Participation: The 1996 Election Season", paper prepared for delivery at the 1997 Annual Meeting of the American Political Science Association, Washington D. C., August 28-31, p. 2.

9. Mike Jensen, 1997. "Internet Connectivity for Africa", September, p. 1, at http://demiurge.wn.apc.org/a frica/afstat.htm, p. 1.

10. Lishan Aden, 1995. "Electronic Communications Technology and Development in Africa", at http://www.sas.upe nn. edu/African_Studies/ASA/lish.html, p. 5.

11. Aden, 1995. "Electronic Communications Technology and Development in Africa", at http://www.sas.upe nn. edu/African_Studies/ASA/lish.html, p. 6.

12. Christopher R. Kedzie, 1996. "'African Connectivity, Problems, Solutions and Actions: Some Recommendations from INET'96"', paper presented at the 1996 Annual Meeting of the Internet Society (INET), at http://wwww.nsrc.org / Africa/regional-reports/inet.txt

13. Etienne Baranshamaje, Eugene Boostrom, Vidoje Brajovic, Masud Cader, Robert Clement-Jones, Robert Hawkins, Peter Knight, Robert Schware and Hugh Sloan, 1995. "Increasing Internet Connectivity in sub-Saharan Africa: Issues, Options, and the World Bank Group Role", draft paper, March 29, Washington, D. C.: The World Bank, pp. 6-7.

14. Helge Ronning, 1994. Media and Democracy: Theories and Principles with Reference to the African Context. Harare: Sapes Books, p. 16.

15. Ronning, 1994. Media and Democracy, p. 18-19.

16. Richard R. Fagen, 1966. Politics and Communication, p. 150. 


\section{Bibliography}

Lishan Aden, 1995. "Electronic Communications Technology and Development in Africa", at http://www.sas.upe nn. edu/African Studies/ASA/lish.html

Lishan Aden, 1996. "African Connectivity, Problems, Solutions and Actions: Some Recommendations from INET'96", paper presented at the 1996 Annual Meeting of INET, at http://www.nsrc.org/ Africa/regional-reports/inet.txt

African Agenda, 1997. "The Internet in the South: What Gains? What Dangers?" African Agenda, Volume 11, pp. 23-24.

G. Scott Aikens, 1996. "History of the Minnesota Electronic Democracy Project", paper presented at the Annual Conference of the Internet Society (INET'96), Montreal, at http://www.isoc.org/isoc/whatis/conferences/inet/96/proceedings/e9/e9_1.htm

Robert H. Anderson, Tora K. Bikson, Sally Ann Law, Bridger M. Mitchell with Christopher Kedzie, Brent Keltner, Constantijn Panis, Joel Pliskin, and Padmanabhan Srinagesh, 1995. Universal Access to E-Mail: Feasibility and Societal Implications. Washington, D. C.: RAND, at http://www.rand.org/publication s/MR/MR650

Etienne Baranshamaje, Eugene Boostrom, Vidoje Brajovic, Masud Cader, Robert Clement-Jones, Robert Hawkins, Peter Knight, Robert Schware and Hugh Sloan, 1995. "Increasing Internet Connectivity in sub-Saharan Africa: Issues, Options, and the World Bank Group Role", draft paper, March 29, Washington, D. C.: The World Bank.

Frank Beacham, 1997. "The Internet: Will it Become the Next Mass Media?" In: Media and Democracy: A Collection of Readings and Resources. Washington D. C.: Institute for Alternative Journalism, at http://www.igc.apc.org/an/bo ok/beacham7.html

Bruce Bimber, 1997. "The Internet and Political Participation: The 1996 Election Season", paper prepared for delivery at the 1997 Annual Meeting of the American Political Science Association, Washington D. C., August 28-31.

Graeme Browning and Daniel J. Weitzner, 1996. Electronic Democracy : Using the Internet to Influence American Politics. Wilton, Conn.: Online.

James Deane, 1997. "US to Slash Telecom Payments to Africa", Electronic Mail \& Guardian, February 20, at http://www. mg.co.za /mg/news/97feb1/20feb-telecom.html

Jean-Yves Djamen, Dunia Ramazani and Stephane Soteg Some, 1995. Networking in Africa: An Unavoidable Evolution Towards the Internet. Departement d'Informatique et de Recherche Operationnelle (IRO), Universite de Montreal, Technical Report 937 (January), at htt p://www.sas.upenn.edu/African_Studies/Padis/telematics_Rmzani.html

Festus Eribo, Oyeleye Oyediran, Mulatu Wubneh and Leo Zonn (Editors), 1993.Window on Africa: Democratization http://www.firstmonday.dk/issues/issue3_4/Ott/ (16 of 18) [8/5/2008 4:19:22 PM] 
and Media Exposure. East Carolina University, Center for International Programs, Publication No.1 (March).

Richard R. Fagen, 1966. Politics and Communication. Boston: Little, Brown.

Katherine Fulton, 1997. "http://www.journalism.now - Tour of our Uncertain Future", In: Media and Democracy: A Collection of Readings and Resources. Washington D. C.: Institute for Alternative Journalism, at http://www.igc.apc.org/ an/boo k/fulton7.html

Global Knowledge, 1997. "Recommendations and Cases from the GKD97 List", Global Knowledge 97, Document Archives, at http://www.globalknowledge.org

Gerald G. Grant, 1995. "Implementing Electronic Networking in Africa: The Case of GOVERNET", at h $\mathrm{ttp}$ ://www.sas. upenn.edu/African_Studies/Padis/telematics_Grant_18.html

Lawrence K. Grossman, 1996. The Electronic Republic: Reshaping Democracy in the Information Age. New York: Penguin.

Shanto Iyengar, Donald R. Kinder and Benjamin I. Page, 1989. News That Matters: Television and American Opinion. Chicago: University of Chicago Press.

Mike Jensen, 1996. "Bridging the Gaps in Internet Development in Africa", International Development Research Centre Study (August 31), at http://www.idrc.ca/acacia/s tudies/ir-gaps.htm

Mike Jensen, 1997. "Internet Connectivity for Africa", September, at http://demiurge.wn.apc.org/a frica/afstat.htm

John Abdul Kargbo, 1997. "The Internet in Sierra Leone: The Way Forward?" First Monday, Volume 2, at http:// www.firstmonday.dk/issues/issue2_2/kargbo/

Christopher R. Kedzie, 1996. "'African Connectivity, Problems, Solutions and Actions: Some Recommendations from INET'96"', paper presented at the 1996 Annual Meeting of the Internet Society (INET), at http://wwww.nsrc.org / Africa/regional-reports/inet.txt

Hans K. Klein, 1995. "Grassroots Democracy and the Internet: The Telecommunications Policy Roundtable - Northeast USA", paper presented at the Annual Conference of the Internet Society (INET'95), Honolulu, at http://www.isoc.org/HMP/ P APER/164/txt/paper.txt

David Lush, 1997. "Mainlining on e-mail", Electronic Mail \& Guardian (February 5), at http://www.mg.co.za / mg/news/97jan2/5feb-Internet.html

Lewis Machipisa, 1997. "Development: Knowledge, a Weapon against Poverty", InterPress Service (June 24).

James Madison, 1787. Federalist Papers: Federalist No. 10, From the New York Packet, Friday, November 23, at http://lcweb2.loc.gov/const/fed query.html 
Gumisai Mutume, 1997. "Is Africa ready for the Superhighway?" Electronic Mail \& Guardian (May 16), at http://www.mg. co.z a/mg/news/97may2/16may-Internet.html

Gumisai Mutume, 1997. "Africa-Development: More than just Internet Connections Required", InterPress Service (June 24).

Gumisai Mutume, 1997. "Wiring up Africa -- and Beyond", Electronic Mail \& Guardian (June 25), at http://www.mg.co.za/ mg/news/97june2/25june-Internet.html

Olat unji Ogunyemi, 1995. "Brave New World Order", West Africa, (March 20-26), pp. 422-23.

PANOS, 1995. "The Internet and the South: Superhighway or Dirt-track?" at http://www.onewor ld.org/

panos/panos_Internet_press.html

Helge Ronning, 1994. Media and Democracy: Theories and Principles with Reference to the African Context. Harare: Sapes Books.

UNESCO. 1994. Statistical Yearbook. Paris: United Nations Educational, Scientific and Cultural Organization.

USIA, 1995. "Foreign Radio is a Major News Source in Niamey and Zinder, Niger", Audience Analysis, U. S. Information Agency, Office of Research and Media Reaction (April 13).

Martin Vystavil, 1995. "Internet: Supporting Democratic Changes in the Post-Communist Slovak Republic", paper presented at the Annual Conference of the Internet Society (INET'95), Honolulu, at http://www.isoc.org/HMP /PAPER/089/html/

paper.html

Darrell M. West, 1993. Air Wars: Television Advertising in Election Campaigns, 1952-1992. Washington D. C.: Congressional Quarterly.

Ernest J. Wilson III, 1995. "Africa and the Global Information Infrastructure", Africa Communications, (May/June), pp. 40-43.

Dhyana Ziegler and Molefi K. Asante, 1992. Thunder and Silence: The Mass Media in Africa. Trenton: Africa World Press.

\section{Contents Index}

Copyright $@$ @ 1998, i ${ }^{\circledR} \mathrm{s}-\mathrm{m} \propto \tilde{\mathrm{n}} \mathrm{d} @ ¥$ 